\title{
A Tale of Three Women: The Visual Arts In Canada / A Current Account/ing
}

\section{Joyce Zemans}

Volume 25, numéro 1-2, 1998

Producing Women

Ces femmes qui produisent ...

URI : https://id.erudit.org/iderudit/1071618ar

DOI : https://doi.org/10.7202/1071618ar

Aller au sommaire du numéro

\section{Éditeur(s)}

UAAC-AAUC (University Art Association of Canada | Association d'art des universités du Canada)

\section{ISSN}

0315-9906 (imprimé)

1918-4778 (numérique)

Découvrir la revue

Citer cet article

Zemans, J. (1998). A Tale of Three Women: The Visual Arts In Canada / A Current Account/ing. RACAR : Revue d'art canadienne / Canadian Art Review, 25(1-2), 103-122. https://doi.org/10.7202/1071618ar

\section{Résumé de l'article}

Cet article examine le statut de quelques femmes artistes canadiennes à la fin du XXe siècle. Il aborde la question sous divers aspects et, en particulier, sous celui de la nature institutionnelle de la discrimination et de son impact économique et idéologique sur la vie et sur les moyens de subsistance des femmes artistes. Il analyse aussi l'importance des pratiques et des politiques du musée, de la galerie, des agences subventionnaires et de l'environnement éducatif post-secondaire afin de comprendre comment les institutions appliquent ou transforment les hiérarchies de l'histoire traditionnelle de l'art. L'article se divise en deux parties : la première est une analyse qualitative où sont examinés trois cas de femmes artistes torontoises qui contestèrent le discours critique dominant à des périodes différentes du XXe siècle. Il s'agit de Kathleen Munn qui oeuvra principalement entre 1918 et 1935, de Joyce Wieland dont la carrière s'étend sur une trentaine d'années, soit de la fin des années cinquante à la fin des années quatre-vingt, et enfin de Vera Frenkel qui est à la fine pointe de la création artistique canadienne depuis le milieu des années soixante-dix.

La seconde partie analyse l'histoire du soutien institutionnel accordé aux femmes artistes d'un point de vue quantitatif. J'examinerai ici aussi trois cas: celui du Musée des beaux-arts du Canada, du Conseil des arts et de l'Ontario College of Art (la plus ancienne et la plus grande école d'art du pays). Je terminerai cet article en concluant que si les femmes se sont imposées de manière significative dans le monde de l'art canadien et que leur production a contribué de façon cruciale à la formulation des discours esthétiques postmodernes, les vieux préjugés qui accordaient au travail des femmes une valeur moindre qu'à celui de leurs vis-à-vis masculins, n'ont pas disparu : la production des femmes reste moins exposée et moins achetée que celle des hommes, celles-ci ont plus de difficultés à obtenir des subventions et des postes universitaires et elles gagnent, dans la plupart des cas, moins bien leur vie. Les faits indiquent que la réinsertion des femmes comme " Autre » ne suffit pas et que des stratégies novatrices sont requises pour remodeler les approches historiques et théoriques traditionnelles. Nous devons non seulement corriger les manuels d'histoire, mais aussi en élargir le cadre historique, exiger de nouvelles conceptions historiographiques qui transformeront le discours pour le rendre plus inclusif.
Tous droits réservés (C) UAAC-AAUC (University Art Association of Canada | Association d'art des universités du Canada), 2001
Ce document est protégé par la loi sur le droit d'auteur. L’utilisation des services d'Érudit (y compris la reproduction) est assujettie à sa politique d'utilisation que vous pouvez consulter en ligne.

https://apropos.erudit.org/fr/usagers/politique-dutilisation/ 


\title{
A Tale of Three Women: The Visual Arts In Canada / A Current Account/ing
}

\author{
JoYCE ZEMANS, York UNIVERSITY
}

Résumé et article examine le statut de quelques femmes artistes canadiennes à la fin du XXe siècle. II aborde la question sous divers aspects et, en particulier, sous celui de la nature institutionnelle de la discrimination et de son impact économique et idéologique sur la vie et sur les moyens de subsistance des femmes artistes. II analyse aussi l'importance des pratiques et des politiques du musée, de la galerie, des agences subventionnaires et de l'environnement éducatif post-secondaire afin de comprendre comment les institutions appliquent ou transforment les hiérarchies de l'histoire traditionnelle de l'art. L'article se divise en deux parties : la première est une analyse qualitative où sont examinés trois cas de femmes artistes torontoises qui contestèrent le discours critique dominant à des périodes différentes du XXe siècle. II s'agit de Kathleen Munn qui oeuvra principalement entre 1918 et 1935, de Joyce Wieland dont la carrière s'étend sur une trentaine d'années, soit de la fin des années cinquante à la fin des années quatre-vingt, et enfin de Vera Frenkel qui est à la fine pointe de la création artistique canadienne depuis le milieu des années soixante-dix.

La seconde partie analyse l'histoire du soutien institutionnel accordé aux femmes artistes d'un point de vue quantitatif. J'examinerai ici aussi trois cas : celui du Musée des beaux-arts du Canada, du Conseil des arts et de l'Ontario College of Art (la plus ancienne et la plus grande école d'art du pays). Je terminerai cet article en concluant que si les femmes se sont imposées de manière significative dans le monde de l'art canadien et que leur production a contribué de façon cruciale à la formulation des discours esthétiques postmodernes, les vieux préjugés qui accordaient au travail des femmes une valeur moindre qu'à celui de leurs vis-à-vis masculins, n'ont pas disparu : la production des femmes reste moins exposée et moins achetée que celle des hommes, celles-ci ont plus de difficultés à obtenir des subventions et des postes universitaires et elles gagnent, dans la plupart des cas, moins bien leur vie. Les faits indiquent que la réinsertion des femmes comme «Autre » ne suffit pas et que des stratégies novatrices sont requises pour remodeler les approches historiques et théoriques traditionnelles. Nous devons non seulement corriger les manuels d'histoire, mais aussi en élargir le cadre historique, exiger de nouvelles conceptions historiographiques qui transformeront le discours pour le rendre plus inclusif.
On the one hand, art history takes as its object of study a form of cultural production and ideology - arc. On the other hand, the discipline itself is a component of cultural hegemony maintaining and reproducing dominative social relations through what it studies and teaches and what it omits or marginalises, and through how it defines what history is, what art is, and who and what the artist is. ${ }^{1}$

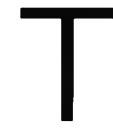

his article examines issues of power and representation in twentieth-century Canadian art. In it, I attempt a stock-taking of the current position of women artists. ${ }^{2}$ My intention is to evaluate the progress of Canada's women visual artists from a variety of perspectives but particularly in terms of the institutional nature of discrimination and its impact, both economic and ideological, on the lives and livelihoods of women artists. Attending not only to what has been said within the discourse of art history, I pay particular attention to museum and gallery practice, to the policies and practices of the granting agencies and to the post-secondary educational field to better understand how institutions articulate or alter the dominant hierarchies of traditional art history.

My goal is to provide an overview. My research builds on the existing literature, including those texts that focus particularly on the context in which women work, such as Monika Kin Gagnon's "Work In Progress: Canadian Women in the Visual Arts," statisti- cal analysis such as that of the Women's Art Resource Centre as reported in the Centre's journal Matriart, and those in which the major emphasis is on the artists' lives and work. ${ }^{3}$

The essay has two parts. Through an historical overview, I look at the careers of three of Canada's leading women artists, each based in Toronto at different periods in this century, each of whom challenged the dominant critical discourse of her period. I focus on the experience of Kathleen Munn whose principal period of production was from 1918 to 1935; Joyce Wieland whose career spanned the period from the 1950s to the late 1980s; and Vera Frenkel who has been at the cutting edge of artistic creation in Canada since the mid-1970s. In each case, I examine the degree to which the "real" history of art has been altered and, as a corollary, pose the question of whether that history is, except at the margins, essentially inalterable. ${ }^{4}$

These case studies serve as an introduction and complement to the second part of the essay in which I analyse the history of institutional support of visual artists in Canada and examine the situation of these artists in particular and women artists in general from a quantitative perspective. The three examples of institutional support which I include are the $\mathrm{Na}$ tional Gallery, the national exhibiting and collecting institution in the field of Canadian art; the Canada Council, the principal granting agency to support individual artists (as well as organizations) in Canada; and the Ontario College of Art and Design, 
the oldest and largest art college in the country, as an example of the situation of women artists who teach in post-secondary studio programmes in Canada.

There is little doubt that women have significantly strengthened their position in Canada's art world. Whereas the 1982 Federal Cultural Policy Review Committee pointed to the underrepresentation of women as appointees and employees in cultural agencies, in 1988, when I was appointed director of the Canada Council, I joined female heads of agencies at the $\mathrm{Na}$ tional Gallery, the National Film Board, the National Library and the Social Sciences and Humanities Research Council of Canada. ${ }^{5}$ Yet, I was the first woman appointed to that position, as I had been the first woman appointed Dean of York University's Faculty of Fine Arts in 1985. Though in recent years women have served as president of both the Nova Scotia College of Art and Design and the Ontario College of Art and Design, these cases are still pointed to as unique situations.

Most importantly, such achievements must be weighed against the situation for individual artists. What has changed in their world? Have efforts to address exclusion and inequities succeeded? How influential have the theoretical writings and research of feminist scholars been in improving conditions in which artists work? How successful have we been in altering the hegemonic discourse of art history and in writing new histories which, as Griselda Pollock envisions, will re-imagine the cultural field as space for what she terms "differencing," in which expansionary and interdisciplinary strategies for writing the history of art can occur? ${ }^{6}$

It should be noted that my research deals only with issues of gender and takes as its subject women artists in general (and, in the three case studies, white female artists working in Toronto who challenged conventional practice). While some information can be extrapolated from the findings discussed in this paper and the sources upon which I have drawn, further research addressing issues of race and class remains to be done. Yet, my research does make it clear that, although the position of individual women artists in Canada has improved significantly, we are still struggling with strategies for creating a new and inclusive environment. It also indicates that women artists are still subject to the effects of art history's canonizing discourses and that institutions are still held captive to historical patterns. It remains true that the opportunities for women, as for most artists who belong to a non-canonical social group, remain significantly fewer than those of their white male counterparts. ${ }^{?}$

PART I: A Tale of Three Women

\section{Case Study 1}

Kathleen Munn, one of Canada's earliest modernist painters, was described by Newton MacTavish, a leading critic of her day, as "one of the ablest of the younger women painters and one of

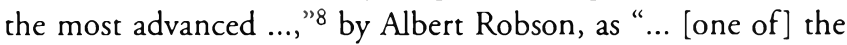
most advanced modernists among the women painters," 9 and by Fred Housser, as "... probably the only painter in Canada whose canvases show an interest in cubism." Housser noted, "More attention might be paid to her if she exhibited in New York or Paris, instead of Canada, where public appreciation of this kind of painting is as yet undeveloped ..."10

Trained in Canada and at the Art Students League in New York, Munn exhibited regularly in the major exhibitions in Toronto during the 1920s. ${ }^{11}$ Her work became an inspiration for Bertram Brooker, acknowledged as one of the most experimental artists and writers of his day. She was invited by the Group of Seven, who actively promoted the work of several of their female colleagues, to participate in their exhibitions in both 1928 and 1930. But the Canadian critics who described and occasionally praised her work did not have a critical context for analysis. More often than not, discussion of her achievements was relegated to that portion of the text which dealt exclusively with women artists. (This was the case with MacTavish's 1925 The Fine Arts in Canada and Robson's 1932 Canadian Landscape Painters which each devoted a chapter to women artists; Housser's essay on Canadian painting in the 1928/29 Yearbook of the Arts in Canada also isolated discussion of the work of women artists. ${ }^{12}$ ) When later texts on Canadian art were written, the material in those chapters and essays which dealt with the work of innovative women artists were often omitted from the records. By the time that Dennis Reid's widely used text, $A$ Concise History of Canadian Painting, first appeared in 1973, Munn had disappeared from the record, and her work was virtually unknown. ${ }^{13}$

This was the case despite the fact that a woman artist in Toronto in the first decades of this century would appear to have had excellent possibilities of success. The art societies regularly showed women's work, and women were often in the majority as art school students. The Women's Art Association of Canada (WAA), dedicated to educating women and to encouraging women artists and focusing on "mutual help and improvement," was active in Toronto, offering a regular programme of exhibitions and lectures. The WAA, however, tended not to include among its members those more ambitious artists who challenged existing art world conventions. Nor did it offer an avenue towards the broader recognition in the critical art world which Munn sought, and there is no evidence that Munn took advantage of either the community or the exhibiting opportunities that the WAA might have provided.

Between 1909 and 1927, seeking recognition for her work, Munn, like many other women artists, exhibited regularly in exhibitions such as those of the Royal Canadian Academy (RCA), the Ontario Society of Artists (OSA), the Canadian National 
Exhibition, and the Art Museum of Toronto. However, positions of power and responsibility in those institutions were generally reserved for men. Though women were occasionally admitted as members, neither the RCA nor the OSA permitted women to be elected to their councils or attend meetings; unable to vote, they had virtually no input into the running of the organizations. ${ }^{14}$ According to Newton MacTavish, this discrimination perpetuated "art for man's sake." ${ }^{5}$ It was the senior academicians, all of them men and generally conservative in their practice and their taste, who not only formed the juries but determined what would be collected from those exhibitions. The results of this hidden bias are evident today in Canadian institutional collections: the works purchased by the juries of the annual Canadian National Exhibition were placed on long-term loan with the Art Gallery of Toronto, and RCA diploma pieces formed the basis of the Canadian collection of the National Gallery of Canada, each collection woefully illrepresented in the case of women artists of this period.

Membership in the major social and cultural associations in Toronto frequented by artists, musicians, leaders in theatre, critics and patrons - in short, Toronto's cultural elite - was also restricted to men. Thus, though Munn was highly respected by her modernist colleague, Bertram Brooker, she, unlike he, did not have access to the Arts and Letters Club for the exhibition of her work or for the personal support which it provided him. (Though Brooker found limited understanding for his more experimental work at the Club, it offered companionship, opportunities to work in a cross-disciplinary manner with, for example, theatre artist Herman Voaden, and access to patrons such as Harold Tovell. ${ }^{16}$ ) Moreover, the Arts and Letters Club and Hart House strongly influenced the taste of collectors of contemporary art and public patrons. It would be 1972 before Hart House admitted women members and 1985 before the Arts and Letters Club formally permitted women to join the Club. ${ }^{17}$

Munn's critical acceptance was not only influenced by her gender. The fact that she chose to work within the framework of contemporary modernist practice in a period in which the dominant cultural aesthetic had no place for those whom Frederick Housser labelled "putterers in the blind alley of abstraction," 18 was likely the paramount issue in the lack of institutional recognition for her work. Despite the fact that the Group of Seven had invited Munn to exhibit with them, the prevailing approach to early twentieth-century Canadian art tended to exclude from the record individualism and diversity in favour of a reflection of the national cultural agenda which Housser and the Group were instrumental in promoting. However, gender certainly compounded the problem. Describing the period, Maria Tippett has written, "women [were] either totally ignored by the critics or written about according to gender-based criteria." 19 Women whose work conformed to the male values which underlay the dominant aesthetic were less likely to suffer Munn's fate. Yvonne McKague, whose work Housser described as having "masculine strength and intellectuality" and who could "handle big material in a big way," 20 was one of the few women artists to be hired to teach painting at the Ontario College of Art, despite the fact that the majority of students were most often women.

When Housser wrote about Bertram Brooker, he did not suggest that he would do better exhibiting elsewhere, as he did in Munn's case. Nor was Brooker, who was also experimenting with abstraction in these years, written out of the historical record. Kathleen Munn, on the other hand, as a woman who challenged the meta-narrative of the landscape tradition, would have to wait for feminist revisionists to rediscover her work and its importance.

At the end of her life, desperate to establish the importance of her art and to locate it in Canadian art history, Munn wrote and rewrote a letter petitioning to have her work included in the National Gallery's seminal exhibition, Canadian Painting in the Thirties. The letter, written to curator, Charles Hill, at the National Gallery of Canada in 1974, may in fact never have been sent. In it, Munn wrote "... My work is my concern. I allowed myself to be out of sight for so long ... I wish to see my work $[s]$ recognized and appreciated, instead of being hidden away and not exhibited, as they should have been ...."21 Once representative of the vanguard of modernism in Canadian art, Kathleen Munn, like a number of her female contemporaries, was lost to the record.

Only after the 1988 retrospective exhibition of her work, for which paintings were collected from under the beds and the backs of the closets of her relatives, did Munn re-enter the history books. ${ }^{22}$ In contemporary literature, she now figures in historical discussions of the period in which she worked, and during the last several years, her art has been collected by both public galleries and private collectors.

\section{Case Study 2}

Our second case study, Joyce Wieland, came to artistic maturity in the 1950s, twenty years after the Group of Seven was officially disbanded. Dennis Reid has written that, at the time, A.Y. Jackson still represented "the heart and soul of vital painting in [Toronto] - in fact in most of English-speaking Canada." ${ }^{23}$ Though modernist art had been exhibited regularly in Toronto throughout the 1940s and Painters XI had begun to exhibit as a group by 1953, Jock Macdonald, who had been teaching at the Ontario College of Art since 1947, described the 1950s as a period of often pitched battles between the traditionalists and the modernists in teaching at the Ontario College of Art and in exhibition fora such as the Canadian National Exhibition. 
To a certain extent, Wieland side-stepped those issues. With other artists of her generation, she recognized that her search was different. She sought a personal voice and idiom from vircually the beginning of her practice. Her concerns were neither the landscape tradition which had for so long captured the Canadian imagination nor the dominant language of $\mathrm{Ab}$ stract Expressionism which engaged a number of her contemporaries.

In a 1970 interview, Wieland described her conscious search for "female lines of influence as she started to invent [her] self as an artist." Eventually "women's concerns and [her] own femininity became [the] artist's territory." ${ }^{24}$ Among other things, the search led her to the use of domestic and craft materials to challenge the dominance of painting and the traditional materials of high art. Instead, Wieland employed the materials which form the stuff of women's daily lives, exploring models of collaboration and collective creation. Questioning traditional hierarchies and the separation of high and low art, she commissioned craftswomen to create works for her 1971 National Gallery exhibition, legitimating the place of women's domestic craft in high art institutions. ${ }^{25}$

Feminist critic, Lauren Rabinovitz, was one of the first to grant Wieland pioneer status among North American women artists, offering a more comprehensive interpretation of her work. ${ }^{26}$ Comparing Wieland's 1971 National Gallery retrospective, True Patriot Love/Veritable Amour Patriotique, with Judy Chicago's The Dinner Party (1979), Rabinovitz argued that the apparent naiveté of Wieland's show masked "a rigorous intellectualism." She identified the uniqueness of work that

introduced feminist concerns such as the incorporation and celebration of women's craft heritage (through her quilts, etc.), the reclamation of women's sexual self-identities (by attempting to balance the difference between high and low art), and the utilization of a method which allows active audience participation (through her catalogue, a documentation of the show as a work-in-progress which the reader was invited to thumb through, thus completing Wieland's artistic action by creating a separate set of photo/word/ picture juxtapositions). ${ }^{27}$

It was these approaches, posited Rabinovitz, upon which North American artists, like Chicago, would elaborate.

Wieland's 1983 painting, The Artist on Fire, speaks to her mature philosophy and her questioning of the traditional roles of artist and model. Her most powerful self-portrait, this painting represents a reversal of the traditional artist/model relationship. It shows the artist in full control of fire, the creative force. Commenting on the painting, cultural theorist, Linda Hutcheon has written:

\begin{abstract}
The female painter-figure is the source of fire in a number of senses, as her body is shown "on fire" and her brush paints flames. The passion suggested by being "on fire" is seemingly directed towards art and towards the male only as represented - or created - in art. In inverting Genesis, Wieland ironically empowers woman as the god-like creator. $^{28}$
\end{abstract}

Though she was described in 1987, at the time of her retrospective exhibicion at the Art Gallery of Ontario, as Canada's foremost woman artist, there were few times in her artistic career when Wieland ever felt that her work had received the critical attention it deserved.

Yet Wieland was a success story - at least in comparison with many of her women colleagues. Remarkably, the 1971 exhibition, True Patriot Love, was the first major solo exhibition that the National Gallery of Canada had dedicated to the work of a living woman artist. Even harder to believe, the exhibition of her work at the Art Gallery of Ontario in 1987 was the first time that the AGO had mounted a major retrospective exhibition of a living Canadian woman artist. The exhibition appears in the end to have been mounted in large measure due to the pressure brought to bear by Wieland's admirers and by Wieland herself who, recognizing the importance of public acknowledgement, had, uncharacteristically, in the mid-1980s begun to petition for what she believed to be her due. Wieland later told Susan Crean, "In the strange convoluted world of art, you see, artists are not supposed to ask. Like women in the traditional marriage market, etiquette demands that you wait to be noted; an exhibition solicited somehow doesn't count, implying interference with the natural course of curatorial judgment." 29

At the time of the 1987 retrospective exhibition, John Bentley Mays, the art critic for Canada's national newspaper, criticized Wieland for not having found a single voice and style. Addressing the shifts which reflected Wieland's ongoing attempt to challenge prevailing modernist notions of art, Mays described her work as "scattered" and her intentions as "unresolved," arguing that only in the case of film had she ever successfully "mastered" her medium. ${ }^{30}$ Summing up the general reception to the exhibition, Mays wrote that the media "... wanted to use this show as an occasion to shower bouquets on Wieland as a phenomenon - a woman of great personal charm and beauty, an exemplary Canadian patriot, feminist, defender of the earth, survivor of many neglects and troubles, and not as a visual artist." 31 Mays was accurate in that regard. Since she had come to maturity at the beginning of the second phase of feminism, Wieland's reputation had been constructed mainly in terms of her position as a woman artist rather than through a critical analysis of her work.

An examination of the reviews of Wieland's work over the 
span of her career reveal that, especially during the first decades, few reviewers were able to get beyond her gender to grapple intelligently with the work. Critics focused on Wieland as "personable" and "lovable" or on her "simplicity" and "naivete." Writing of her work when she had already established a pioneering position for herself in the New York structuralist film world, Toronto critic Barrie Hale described her as the "cute and charming" wife of Michael Snow. ${ }^{33}$ Wieland herself was painfully aware of the problem. In 1987, she reported to a Toronto writer that "every review, slide, letter and invitation to lecture had been sorted out and saved and that this collection confirmed that not much literature of consequence actually existed with regard to her and her work." 34

Wieland's work as a film-maker offers an interesting case study into the reception of the work of women artists concerned with issues of gender and gender politics. Coming to prominence in the mid-1960s, at the same time as structural filmmaking (as it would come to be known), Wieland's films such as 1933 (1967), Sailboat (1967), Catfood (1968) and Rat Life and Diet in North America (1968), were critically lauded, establishing her reputation in both the United States and in Canada. In the 1969 article which defined the structural film movement, film critic and editor of Film Culture magazine, P. Adams Sitney, emphasized Wieland's importance, arguing that Reason over Passion "deconstruct[ed] the material processes of images and their roles in "ideology'." 35

Yet, as the aesthetic focus of the New York film scene hardened, defining the avant-garde in terms of its rigorous intellectual and self-reflexive stance on the formal processes of film-making, Wieland found herself increasingly marginalized. ${ }^{36}$ While Sitney would later admit Wieland's husband, Michael Snow, to the canon as a film-maker engaged with the "intense almost philosophical speculations on cinema itself," that modernist canon offered little room for Wieland's concern for issues of identity and gender, nationalism and the environment.

Though the importance of films like Water Sark was understood by film historian and film-maker, Kay Armatage Armatage described it as "a practice of image construction through which [Wieland] is able to operate the feminine over the male body in a very literal displacement of the phallic" - it, not surprisingly, found little sympathy in the critical world dominated by Andy Warhol's minimalist films. ${ }^{37}$ When the Anthology Film Archives were formed in 1970, Wieland, Shirley Clarke and Maya Deren, all active members of the New York film scene, were excluded. In the ideology of the men who defined the movement, canonization of the "monuments" of cinema rested exclusively on film-making as a formalist activity. Wieland never fully recovered from the hurt of her exclusion from the Archives.

Wieland was disappointed that when the 1987 Art Gallery of Ontario exhibition was finally mounted, although it travelled to the Confederation Centre Art Gallery and Museum in Charlottetown, the Beaverbrook Art Gallery in Fredericton and the Mackenzie Art Gallery in Regina, it was not exhibited in Ottawa, Montreal or Vancouver. Reviewing the exhibition catalogue, cultural theorist Kass Banning argued that "instead of pointing to Wieland's uncanny ability to decode the existing (and accepted) artistic structure in order to create new possibilities for interpretation," the authors had, while focusing on her status as a pioneer, failed to lift her oeuvre into the critical feminist discourse of the $1980 \mathrm{~s} .{ }^{38}$ Banning also pointed out that, without an indigenous Canadian critical context for the discussion of feminist art, it was impossible to develop a comprehensive interpretation of Wieland's art.

Though Wieland did not hold a regular teaching position, she was committed to a circle of younger painters for whom she was an exemplar. Well aware of the importance of role models, she attributed her own recognition of the possibility of a career in art to Doris McCarthy, her teacher at Central Technical School in Toronto. Though her National Gallery exhibition had been sensitively mounted by Pierre Théberge, it was primarily the new generation of feminist critics and historians who understood her work and brought to it the analysis and criticism it required. Unlike Munn, Wieland was prepared to fight for recognition at key moments in her career, and unlike Munn, she was relatively successful in her struggle for acknowledgement. On her death in 1998, mini-retrospectives of her films and her art were held across Canada. Her work is not in danger of being overlooked by future generations. It hangs in major collections across the country and will, in the end, have the opportunity to speak for itself.

\section{Cose Study 3}

Our third case study, Vera Frenkel, came to maturity in the 1970s. Unlike Munn and Wieland, she was eventually able to find a place in the academic community, despite the fact that the number of women teaching in the studio area in postsecondary institutions in Canada continues to remain significantly below that of their male counterparts. As an excellent teacher, a mentor, a role model, and as a full-time faculty member first at the University of Toronto and then at York University (until 1995), Frenkel has, more than either of the other artists discussed, had the opportunity to play an important role in shaping the careers of many of today's contemporary practitioners in the visual arts in Canada, an opportunity still denied to most women artists of her generation. Former students speak with admiration of the importance of her teaching and mentoring in their professional lives. At York, she was promoted to the rank of full professor in recognition of her professional achievements and her teaching. Yet, Frenkel's expe- 
rience within the institution was frequently fraught with anxiety. As with most women faculty members, particularly those hired in the 1970s, her salary was lower than those of her male peers, and she had to petition to address the situation. ${ }^{39} \mathrm{~A}$ superb teacher, she found her opportunities for curricular innovation were often limited. Bureaucratization combined with lack of understanding of a vision that did not match the dominant perspective of the institution, along with the tightening financial circumstances of universities, made the realization of academic projects difficult and sometimes impossible. ${ }^{40}$ Ultimately, Frenkel left the university, determined to devote her energy full-time to her studio practice.

First recognized internationally as a printmaker and sculptor, Frenkel, since 1972, has been in the forefront of the visual, spatial and narrative uses of video and media-based art. Her earliest work in this field saw the beginning of her ongoing investigation of questions of language, codes and signs and the construction of meaning, examining "how we come to know what we know." 41 This led her to an exploration of the mythic properties of popular culture and, later, of the collusive relations between government and citizen, as in the impact of censorship. $^{42}$

Preoccupied with issues of identity, memory and exile and the relationship of life (or reality) and art, her video and installation works, featuring the mutual interrogation of documentary and fictional modes, examine how we acquire the knowledge that shapes our existence. ${ }^{43}$ The boundaries between image and representation are constantly reconfigured in a world where the media inform and shape perception; Frenkel's work challenges customary ways of seeing and explores the nature of language and meaning, and vision and perception. Rooted in an interrogation of the abuses of power and their consequences, her work examines received ideas, throwing them into relief and spotting "where they're buried and how they shape our assumptions." 44 Lydia Haustein has written:

Against the growing social and political paralysis that lies like a lead net over everything that promises meaning and has immobilized our sense of social values, Frenkel's works of art, a form of poetry made concrete, consriture a cultural critique and an appeal. 45

As the child of Czech Jews who immigrated to Canada via England, Frenkel speaks in her works to the sense of uprootedness that is characteristic of the immigrant (and, more and more, the Canadian) experience. Her recent work explores the nature of the geographical and historical space, the "tightrope walk" between cultures, and the experience of living between places. ${ }^{46}$ ... from the Transit Bar (1992) consists of individual life stories of exile, asylum, immigration and other cultural and geographi- cal displacements, recounted through monitors in a six-channel video-disk installation/functional piano bar. Created for Documenta IX in Kassel, Germany, the work quickly came to international attention. Since then, it has been the basis for exhibition/installations in Toronto's Power Plant (1994), at the National Gallery of Canada in Ottawa (1996) and, under the auspices of Rijksutstallningar, in venues in Scandinavia and Poland. It offered the departure point for Body Missing, a video installation and website which has also been mounted in a number of European venues and which pursues the notion of displacement from another point of view, here focusing on the madness of collecting fever and the curious fate of works of art looted by the Nazis and destined for the proposed Hitler Museum. ${ }^{47}$ In 1998, Frenkel's work was featured by the Museum of Modern Art's Department of Film and Video "Video Viewpoints" in Inside Exile: Messiahs, Migration and Loss.

Frenkel is currently engaged in the development of The Institute: or, What We Do for Love, a video-Web "poly-serial" narrative work (co-produced with the Stadium Network for the Arts). Based on the travails of a large cultural institution, it examines issues explored in previous videotapes, installations and new media works - "forces at work in human migration, experiences of displacement and deracination, the learning and unlearning of cultural memory, and the bureaucratization of everyday life ..." 48 Without doubt, it also reflects the artist's own experiences with and within institutions.

On the surface, Frenkel represents the gains that women artists have achieved in Canada in the last decade of the century. Her work has been exhibited in major Canadian institutions. Frenkel first represented Canada internationally at the Venice Biennale of 1972 when her work was chosen by an Italian jury from a pre-selection made by the National Gallery. (In that year, two exhibitions of Frenkel's prints and drawings were touring Canada.) In subsequent years, her work has been selected, albeit primarily by foreign juries and curators (with the exception of the $O$ Kanada exhibition in Berlin in 1993), to represent Canada abroad in such venues as the Venice Biennale, Documenta, Andere Körper and Rijksutstallningar. She is one of the relatively few women artists of her generation who obtained a fulltime teaching position and rose to the level of full professor. She has been successful in obtaining grants from the Canada Council, including the prestigious senior A grants. She has, as well, been honoured by her peers and by the artistic community. She has received the Canada Council's Molson Prize for the Arts (1989), the Toronto Arts Foundation's Visual Arts Award (1991) and the Gershon Iskowitz Prize (1993) - awards which, as well as reflecting the esteem of her peers, provided monetary rewards.

Frenkel, like Wieland, recognized early that she would have to struggle for the recognition that was rightfully hers. Though 
her early prints and a number of the videotapes which form an integral part of her installation pieces have been exhibited by major Canadian institutions, major works have been acquired only by the Canada Council Art Bank collection (1985) and the National Gallery (1997). ${ }^{49}$ When ... from the Transit Bar was acquired by the National Gallery of Canada in 1997 (Frenkel's sixtieth year), it was only as a partial purchase (of the video and video-programming elements) accompanied by a donation from Frenkel to the Gallery of the installation itself. ${ }^{50}$

International recognition has come more quickly. Frenkel's work has been exhibited in a Canadian/international context at Expo '86, and at the Venice Biennale and Documenta. In recent years, her work has been the focus of exhibitions throughout Europe and Scandinavia, and the interest in and knowledge of her work abroad has in turn informed the nature of the work.

\section{PART II: A Current Account/ing}

In this post-modern era, public institutions are more aware and more politically conscious than they have been in the past of their responsibility to make their collections representative in terms of gender and race. A number of post-secondary institutions have adopted affirmative action programmes to address the almost insurmountable gap between the numbers of male and female faculty. And, when confronted with the data, grantgiving institutions have altered their processes of selecting juries in an attempt to make opportunities more equitable.

Yet, despite the fact that women represent virtually half of Canada's artists and are at the forefront of much of the work that is being done in the visual arts, they remain under-represented in most of the situations critical to their success. They are less well-represented in public and private galleries and in the texts that document our history. They usually earn less for their work than their male colleagues earn for theirs. They represent a relatively small proportion of Canada's post-secondary teachers, are generally paid less than their male counterparts, and receive less funding than their male counterparts from government-sponsored programmes of support. ${ }^{51}$

What follows in the second part of this paper is an examination of the situation from the perspective of a quantitative analysis. Adopting the materialist approach and its basis in social reality, I examine the degree to which change has been effected. In the case of museums, this is analysed in terms of who and what is collected and exhibited. In the case of grants, it is viewed not only from the perspective of success rates and the number of grants but also the amount of money allocated. In the post-secondary sector, I examine the situation of women artists in teaching. This narrative illustrates the web of circumstances which continues to place women artists at a considerable disadvantage within the Canadian artistic scene. ${ }^{52}$ While others, in Canada and other countries, have undertaken similar research, the current initiative is intended to serve two distinct purposes: to update existing research and to contextualize the data with particular reference to the effect of changing circumstances on individual artists.

First a little history. In 1970, the Royal Commission on the Status of Women in Canada reported that fewer women than men had achieved prominence as creative artists, despite the presence of first-rate artists in Canada who were women; that though women were very successful as interpreters of the arts, there were few who achieved prominence as creators. They also found that, although women predominated as music teachers at the elementary school level, they were heavily outnumbered by men at the college and university levels. (The same argument could easily have been made in every art form. $)^{53}$

A decade later, little had changed. In 1982, the Federal Cultural Policy Review Committee reported that the Canadian Advisory Council on the Status of Women had told them of "the multiple factors which hinder the full participation of Canadian women in our cultural life." 54 The Committee noted particularly the large income gap between male and female artists, the low grant-application rate of female artists, the under-representation of women as appointees and employees in cultural agencies, and the problem of the low visibility of the work of female artists.

In order to make her mark and achieve a reputation for her work, an artist in Canada must succeed on a number of fronts. Success is closely related to reputation. Essential to that reputation is recognition by the institutional infrastructure of the Canadian art world: primarily, the public gallery system, the granting system which offers assistance to individual artists and support for arts organizations, and the post-secondary teaching environment. This part of the paper therefore examines the position of women artists in relation to such institutions.

\section{The National Gallery}

We have already looked at how the National Gallery of Canada responded to the work of the three artists whose careers I have examined. Kathleen Munn did not make it into the Gallery's collection during her lifetime. ${ }^{55}$ Joyce Wieland was, on the other hand, offered a ground-breaking exhibition by a curator who had recognized her achievements and was prepared to challenge historical convention. It must be reiterated that this was the first major solo exhibition of art by a living Canadian woman artist at the National Gallery and certainly did not create a pattern for future activity. In the decade following Wieland's exhibition, there were twenty exhibitions focusing on the work of living Canadian male artists (eight of these major exhibitions). ${ }^{56}$ There were, however, only two small solo exhibitions of the work of women artists (both drawings shows): 
Gathie Falk's "Herd Two" and Drawings (1977) curated by Mayo Graham, documented by a three-page brochure, and the 1978 exhibition of Wieland's drawings for The Far Shore, curated by Pierre Théberge and documented by a sixteen-page tabloid. ${ }^{57}$ (In 1975 Mayo Graham curated the group exhibition, Some Canadian Women Artists, which was documented by a 112-page catalogue.) In the same decade, there were seventeen historic exhibitions dedicated to the work of Canadian male artists (thirteen of them major), though there were none dedicated to the work of women artists. ${ }^{58}$

Wieland is very well represented in the National Gallery collection in all media including her films and quilts. (The majority of her works were acquired at the time of the 1971 exhibition or in the following decade, and there are few works from later periods in the collection. ${ }^{59}$ )

In the case of Vera Frenkel, the National Gallery's curators of both video and contemporary art have clearly recognized the importance of Frenkel's contribution. In 1971, the Gallery circulated two exhibitions, titled Metagravures/Printmaking Plus of Frenkel's prints, illustrated by a one-page folded poster-catalogue by Ann Chudleigh. The Gallery holds a solid collection of her videos. In 1985, it mounted Vera Frenkel: the video tapes, a retrospective of Frenkel's video work, documented by a 41 -page illustrated brochure. ${ }^{60}$ In 1996, the National Gallery exhibited ... from the Transit Bar and Frenkel's world wide web site, Body Missing. Yet, as noted previously, when the National Gallery eventually acquired ... from the Transit Bar, after a long discussion with the artist, it was not as a straight purchase but as a combined purchase/donation arrangement. ${ }^{61}$

As Clive Robertson has noted, "compared with similar purchasing budgets of European or American institutions there is not a lot of acquisitional monies available for major Canadian art museums." 62 At the National Gallery of Canada, an annual non-lapsing appropriation of $\$ 475,000$ (from the annual acquisitions budget of $\$ 3$ million) can be spent on contemporary art; this can be accumulated from year to year for larger annual total expenditures. ${ }^{63}$ Funding for major purchases, however, is hard to come by. As with many other contemporary art collecting institutions, a significant amount of contemporary Canadian art comes through donations rather than purchases.

In The 50\% Solution, Anne Innis Dagg castigates the $\mathrm{Na}$ tional Gallery, arguing for equality for women artists in Canada. The author describes a 1984 visit she made to the National Gallery as part of an empirical study of Canadian galleries. ${ }^{64} \mathrm{Of}$ the 110 pre- 1914 works on display, none was by a woman. In what she deemed the modern period (between the wars), only $7 \%$ of the works were by women. In the contemporary (defined as work created post-1945) Canadian exhibition rooms, only $3 \%$ of the thirty-eight works installed were by women. (Almost all of the other public galleries she surveyed at the time did better than the National Gallery in representing the work of Canadian women artists. ${ }^{65}$ )

Dagg's expectations were, I would argue, unrealistic. The re-examination of the work of women artists of earlier periods had really only begun at the time, and there were few recognized exceptions to the canon. Indeed, the gap is so great that, even in those institutions which, like the National Gallery in recent years, have focused on acquiring works by women who have been recuperated into the art historical narrative, it is not productive to analyse a collection with the expectation of obtaining equal representation of women artists in historic collections. While the work of artists such as Paraskeva Clark, Emily Carr and Pegi Nicol MacLeod were collected to a certain extent during their lifetimes, the task of filling the lacunae in relation to women artists in the collection remains. Recent National Gallery acquisition reports (1990-96) indicate that, each year, one or more works by artists such as Emily Carr (1991-92), Sybil Andrews (1991-92), Kathleen Munn (1990-91 and 199394), Alexandra Luke (1992-93), Frances Loring (1993-94), Marcelle Ferron and Anne Savage (1994-95), Kathleen Daly (1995-96), and Sybil Andrews and Elizabeth Wyn Wood (199596) have been acquired as donations or purchased. Not unexpectedly, however, the large majority of works acquired for the Canadian historical collection are by men. Even in the case of post-war art, where one might expect the situation to be different, women artists continue to be relatively poorly represented.

The 1990 Hurtig publication, Masterpieces of Canadian Art from the National Gallery of Canada by art historian and curator, David Burnett, who was also the co-author of a 1983 text on contemporary Canadian art, offers evidence of the situation. ${ }^{66}$ Though it contains illustrations by 87 artists, only 9 of those artists are women. Again, while it might be legitimate to expect a document covering over two hundred years of art to be heavily weighted towards male artists, it is less understandable why, in the case of artists working primarily in the post-1960 era, the book illustrates the work of 28 male artists and only 6 women. ${ }^{67}$

Between 1981 and 1991, nine of the thirty exhibitions (historical and contemporary) of individual Canadian artists' work were by women artists. Five of them were major exhibitions which focused on the work of living Canadian women artists: Liz Magor (with Ian Carr Harris curated by Jessica Bradley for the Canadian Pavilion at the 1984 Venice Biennale); Betty Goodwin, Steel Notes (organized by France Morin for the 1989 São Paolo Biennial); Geneviève Cadieux (organized by Chantal Pontbriand and the Montreal Museum of Fine Arts with the support of the National Gallery for the Canadian Pavilion at the 1990 Venice Biennale); and Jana Sterbak, States of Being, curated by Diana Nemiroff in 1991. ${ }^{68}$ (The 1985 exhibition of Vera Frenkel's videotapes was documented with a 41-page catalogue.) Of the twenty-one exhibitions of the work 
of male artists, sixteen of them were major and twelve represented contemporary artists (eleven of these were major exhibitions). ${ }^{69}$

In 1993, the Women's Art Resource Centre in Toronto, as part of a larger study, commissioned Penelope Stewart to do an analysis of the position of women artists at the National Gallery, comparing the years 1970 and $1993 .^{70}$ Looking at exhibitions of the permanent collection, Stewart reported that in 1970, $16 \%$ of artists whose work was displayed were women. In 1993 , $33 \%$ were women. ${ }^{71}$ In the Canadian historical galleries, Stewart observed that in $1970,4.3 \%$ of the works displayed were by women; in 1993, that percentage inched forward to $6.2 \% .{ }^{72}$

What is most relevant for our purposes are the National Gallery figures regarding the works of contemporary artists. If we accept that women began to work in a professional capacity in large numbers in the 1970s (and represented the majority of students in schools and faculties of fine arts), it would seem appropriate to use installations/exhibitions and acquisitions of contemporary work as a realistic assessment of the current situation. While it is impossible to create exact parallels, since the parameters of measurement have not been constant, an examination of recent installations in the National Gallery's contemporary art galleries offer insight into the changing patterns of exhibiting. In 1993, to celebrate the twentieth anniversary of the Canadian Advisory Council on the Status of Women, Diana Nemiroff, Curator of Contemporary Art, and Janice Seline, Assistant Curator of Contemporary Art, mounted an exhibition from the National Gallery's permanent collection featuring some of Canada's "most prominent and successful [contemporary women] artists." The exhibition included Betty Goodwin, Gathie Falk, Joyce Wieland, Colette Whiten, An Whitlock, Irene Whittome, Joanne Tod, Liz Magor, Spring Hurlbut and Shirley Wiitasalo. ${ }^{73}$ In October 1996, of the 24 works installed in the galleries dedicated to very recent contemporary art (Canadian and non-Canadian), 17 of them (70\%) were by women artists. At the same time, the galleries focused on work from about 1962 to 1985 exhibited 48 works, of which only six were by women (12.5\%). ${ }^{74}$ In February 1999, 32 works by women artists and 50 by men were installed in the contemporary galleries (upper and lower floors). ${ }^{75}$

Despite the National Gallery's mandate "to develop, maintain and make known through Canada and internationally, a collection of works both historic and contemporary, with special but not exclusive reference to Canada ...," it has come under attack for its acquisitions policies vis-à-vis women artists generally and in particular Canadian women artists who, it has been argued, appear to have simply not been a priority. The National Gallery's acquisition history offers an important perspective on the situation of women artists.

In 1982, approximately $2 \%$ of the acquisitions budget allocated to Canadian art was spent on the work of women arcists. ${ }^{76}$ While it is appropriate to argue that acquisitions should be based on criteria other than gender or nationality, it is also important to understand why it is that, when the achievements of Canadian women artists have been widely acclaimed, on a proportional basis so little of the National Gallery's acquisitions budget, exhibition space and programming have historically been allocated towards the work of women.

While questions of medium, scale and importance of a work of art must all be considered in assessing value, statistics regarding expenditures for art by women present a troubling picture. The figures indicate that women's work is simply less likely to be purchased by our public galleries. In 1970, the National Gallery spent $\$ 4,385(7.62 \%)$ on the work of Canadian women artists and $\$ 53,100$ on Canadian male artists' work. Twenty-three years later, in 1993, the Gallery spent $\$ 154,620(15.78 \%)$ on Canadian women artists' work and $\$ 825,308$ on the work of Canadian men. ${ }^{77}$

An examination of the National Gallery's acquisitions policy from the perspective of numbers of works created after 1945 which have been purchased and prices paid for those works provides a more solid basis for analysis. It is interesting to examine the number of works for which the Gallery paid more than $\$ 5000$ between 1990-91 and 1997-98. The percentage of works by women acquired in the post-1945 category ranged from a low of 3 out of 20 works in 1992-93 to a high of 15 out of 22 works in 1994-95. After 1994-95, approximately half of each year's acquisitions in the over $\$ 5000$ price range have been works by women artists. ${ }^{78}$

There are a number of issues that come to the fore in this analysis. If one eliminates the acquisition of works above $\$ 50,000$, it becomes evident that the average prices paid for individual works by women have in recent years been similar to, and sometimes exceeded, the average price paid for work by male artists. ${ }^{79}$ However, while in the higher price ranges there has only been one year (1996-97) since 1990 in which the National Gallery did not acquire at least one work by a male artist in the $\$ 50,000$ to $\$ 500,000$ range, there were four years in which no acquisitions were made in this price range of works by women. Though two works by male artists were acquired in the over half-a-million dollar category in this time period, there were no purchases in this price range of works by women artists. Six works by men and six by women were purchased at over $\$ 100,000$ in this period; of those by women, four were purchased during the fiscal year 1997-98. While the National Gallery purchased eight works by men (vs. four by women) in the $\$ 50,000$ to $\$ 99,000$ range between 1990 and 1998, all of the works by women artists were purchased in or after $1994 .{ }^{80}$ The fiscal year 1995-96 reflects an interesting anomaly. That year, sixty percent of the funds allocated for the purchase of work created after 
1945 was dedicated to women. (The situation is explained by the fact that, in 1995, the Gallery acquired a major work by Agnes Martin, one of the few women artists who has made it into the canon, achieving "star" status in the North American art market. ${ }^{81}$ ) It is also clear that the number of works by male artists from this post-1945 period acquired by the National Gallery significantly outstrips the number by female artists.

Acquisition through donations is, as has been noted, an issue of growing significance if we are to understand the real patterns of institutional collecting. Bill $\mathrm{C1}$, which allows artists to use a $100 \%$ tax credit against earned income for donated works of art of "outstanding significance and national importance," has become important for both galleries and artists. In 1994. Clive Robertson estimated that for many institutions, "the donations-to-purchase ratio, in dollar value, runs minimally at 2:1 and the highest recent figure ... shows a ratio of 10:1."82 Yet, of the 138 post- 1945 donations accepted by the National Gallery in $1997-98,13$ were by women and 125 by men.

The comprehensive figures for the fiscal year 1997-98 provide a picture of the current state of the play. Of the 119 post-1945 works purchased by the National Gallery, 29 (approximately $25 \%$ ) were by women. ${ }^{83}$ Despite some improvement in prices paid, the record indicates that, when purchases and gifts are considered, fewer than $15 \%$ of the National Gallery's total acquisitions of post-1945 works in that year were by women artists ( 42 works by women vs. 249 by men). ${ }^{84}$

There is little question that issues of the market place account in large measure for the discrepancies in prices. Despite the autonomy ascribed to the work of art and celebrated in modern art criticism and practice, reputations continue to be determined in large measure through the relationships between key dealers, curators, critics and artists who constitute the art world and market relationships in major Canadian cities. ${ }^{85}$

We need to understand and acknowledge the interrelationships between value-laden judgements and practices in the art world and the financial rewards and career recognition for arcists that accrue from them. Addressing this issue, Australian cultural theorist, Annette Van den Bosch, suggests that the complexity of the situation is most apparent in countries such as Australia and Canada because of the interrelationships of their markets with the international art market. ${ }^{86}$ In an environment where artistic success is often established in economic terms, value in the art market is measured by the function of art as investment, and public institutions are locked into market value when it comes to purchasing art and evaluating work for donation. ${ }^{87}$ Indeed, were curators and directors not tied to established market values in determining prices paid, a gallery would most certainly be held accountable to its public for setting prices in excess of the existing market values and, consequently, for using public funds inappropriately.
In 1991, women represented only $22 \%$ of the artists displayed in Canadian commercial galleries. Yet a number of these galleries play a vital role in the art scene, building careers and reputations (even participating in auctions to create demand) and, in some cases, financing artists' projects. ${ }^{88}$ Women artists are much more likely to exhibit within the artist-run galleries galleries which are frequented more often by artists than collectors and are seldom in a position to take on the promotional role of their for-profit counterparts. Generational, formal, philosophical and gender issues were at the centre of the establishment of the first collective galleries which introduced new models of artistic practice to audiences across the country. It may be argued that it has been the publicly supported system and the evolving alternative scene that has largely accounted for improvement in the situation of women artists in critical if not monetary terms.

It is clear that there remains a considerable gap between the acknowledged achievements of Canada's women artists (particularly those who have come to maturity in the last twentyfive years) and the current collecting practices of the National Gallery in terms of both prices paid and the number of works collected. ${ }^{89}$

\section{The Canada Council}

The Canada Council's report for 1967-68 indicates the position of women in the arts at the time that the Royal Commission on the Status of Women was holding hearings. Women (primarily performers) received $33 \%$ of the grants in music; $31 \%$ in theatre, only $19 \%$ in visual arts and $12 \%$ in writing. Though the Council awarded grants to artists of either sex in approximately the ratio in which they applied, historically fewer women than men have always applied.

In 1982, the Federal Cultural Policy Review Committee reported that among the submissions to the committee were arguments intending to demonstrate an under-representation of women artists on Canada Council juries and of women artists who were given grants or had their work purchased by the Council's Art Bank. ${ }^{90}$ The arguments were based upon a 1979 study by Jane Martin which calculated that, from 1972 to 1978, women jurors represented from zero to thirty-three percent of Canada Council juries and selection committees. ${ }^{91}$ Subsequent to the report and in response to it, the Council substantially increased the number of women on juries, and by $1982-83$ the percentage had increased to $44 \% .{ }^{92}$ In 1994-95, the situation remained more or less constant; $44.9 \%$ of Council jurors, advisors and assessors were women. ${ }^{93}$ (If frequency of service is factored in, the figure rises to $45.9 \% .{ }^{94}$ ) In the same period, women artists represented $45.6 \%$ of the cultural labour force in Canada. ${ }^{95}$ (According to the Statistics Canada 1993 survey of the cultural labour force, $58 \%$ of Canada's visual artists were 
women. $\left.{ }^{96}\right)$ Statistics Canada also reported, in 1993, that there were 4000 women and 3000 men who declared their primary occupation as painters, sculptors and related artists. ${ }^{97}$

Not surprisingly, there has been a concomitant improvement in the success rate of female applicants. Although statistics indicate that the numbers of applications remain weighted in favour of male artists, an increasingly higher percentage of women artists have tended to compete for and be successful in the individual grants competitions. For example, compared to 1991-92, 1995-96 saw a significant increase in the number of B (mid-range) grants to women, with women receiving 202 grants vs. 200 for men; 262 women applied to the Mid-Career category and 261 men. ${ }^{98}$ However, even with the above-noted improvements, women continued to apply for and tended to receive smaller grants. The significant discrepancy in the number of dollars awarded to women remained, despite the increased success rate as a ratio of applications.

It is also important to note that women were less likely than their male counterparts to progress successfully to the senior category - a situation which, I have suggested in the past, called for the re-examination of the categories and the barriers to success at this stage of competition. The criteria for the largest individual award, the "A" grant, required that an artist must have a national or international reputation extending over a number of years. Yet, all the evidence suggests that it is much more difficult for women to achieve such repucations, given the limited opportunities available for them to have their work purchased by major institutions, to be recognized by the critical mainstream, or to have their work taken seriously in contemporary writing on Canadian art, in short, to be accepted into the still dominant canon. David Foote might also point to the demographic handicap of a generation of women artists, now senior in their professions, who often find themselves competing for grants not only with their peers but with a cohort of even more senior male colleagues and with a younger generation of artists, male and female, who have made the transition to the senior category. ${ }^{99}$

In 1996, the Council announced a new model of awarding individual arts grants. Responsibility for granting was transferred from the Arts Awards section of Council to the disciplinary sections. New categories of grants were introduced, in part to address the loss of the Explorations Program at Council and to provide access for emerging artists. Thus, 1997-98 was a transitional year. Three new categories of artists were introduced: Emerging Artists, Mid-Career Artists and Established Artists. There is now only one competition a year in each category. Experience suggests that the newly announced "Quest Program for Emerging Artists" will provide much needed assistance for female artists at the beginning of their careers. ${ }^{100}$ Though it is only designed to run for two years, it is likely that this strategically designed program to support newly emerging artists will offer an important opportunity for young artists.

The recent establishment of seven Governor General's Awards in the Visual and Media Arts, more than six decades after the creation of the Governor General's Literary Awards and a decade after the Performing Arts awards were inaugurated, is a welcome move. While the $\$ 10,000$ awards will do little to address the financial needs of Canada's senior creative artists, they offer a new level of recognition at the national level for Canada's well-established senior artists in painting and drawing, photography and printmaking, architecture, fine crafts, sculpture and installation, film and video, and audio and new media.

Results of the November 1997 Visual Arts juries are, at first glance, very encouraging. In all, 527 men and 545 women applied: 108 men and 108 women were successful. (The success rate was $20.49 \%$ for men and $19.82 \%$ for women.) Many more women than men applied for grants in the Emerging Artists category (244 vs. 166). In this category, there were more than twice as many grants awarded to women artists ( 42 vs. 20 ), and the success rate was higher for women. In the case of the MidCareer Artists category, women and men applied in almost the same numbers (262 vs. 261), and the success rate was again virtually the same ( 53 women and 50 men: $20.23 \%$ vs. $19.16 \%$ ). It is only in the senior category, Established Artists, which has replaced the "A" grants, that we continue to see significant gender disparity. This is apparent in terms of the numbers of applications (while 39 women applied, there were 100 applications from men) and in terms of success rate ( 13 women and 38 men were awarded grants in this category, reflecting a 33\% success rate for women and a $38 \%$ success rate for men). When one combines the lower number of applications by women and the higher success rate of men, it becomes clear that there is still a significant problem at this level; the problem is exacerbated by the multi-generational bottleneck at this granting level.

If the overall application rates and the success rates for women artists are generally more encouraging, a closer examination of allocation of funds reveals a clear and continuing problem. In the 1997 competition, the Established Artists category awarded a total of $\$ 1,603,000$; Mid-Career Artists received $\$ 1,345,000$; and Emerging Artists (which received the largest number and proportion of applications from women and in which women artists' success rate was highest) were awarded only $\$ 310,000 .{ }^{101}$ Although, in the Mid-Career category, the numbers of applications and the success rate of women and men was more or less equal, in total men received $\$ 710,000$ vs. $\$ 635,000$ for women (indicating an average grant of $\$ 14,200$ for men and $\$ 11,981$ for women). ${ }^{102}$ In the Established Artists categories, the average value of the grants to men and women was approximately the same; indeed, the average 
grant to women $(\$ 31,769)$ was slightly higher than that to male artists (average grant $\$ 31,315)$. However, particularly since so few women (39) compared to men (100) applied and since women had a slightly lower $(33.33 \%)$ success rate than men $(38.00 \%)$, men received $\$ 1,190,000$ whereas women received $\$ 413,000$ in this competition. ${ }^{103}$

While the change in granting categories appears to have been a sensible strategy, it has not yet overcome what I consider to be, largely, barriers of perception associated with the senior grant category. The disappointing number of applications may reflect past negative experiences associated with the senior "A" grants. It also reflects the perception of systemic barriers which limit access to the kind of grants that allow for significant creative opportunities, and the need for women artists to redefine their own sense of accomplishment and worth. Like the National Gallery's history in purchasing major works by senior women artists and the prices paid for those works, the Canada Council's records suggest that a major problem remains for female artists who seek admission to the canon, the prerequisite for institutional support and recognition at the highest level.

\section{The Teaching Institution}

In 1984, a Waterloo University student gave Anne Innis Dagg the outline of a Canadian Art course that she was taking. ${ }^{104}$ Of the twenty-four painters listed by name, only one was a woman - Emily Carr. Carr herself had lamented the difficult position of women artists some fifty years earlier. She would certainly have been shocked to know how little the situation had changed. Neither Kathleen Munn nor Joyce Wieland had made the list. This was not surprising in the case of Munn, whose retrospective exhibition was still four years away, but less understandable in the case of Wieland, who, as we have seen, already had a national reputation and was labelled by some as Canada's foremost woman artist.

When Sasha McInnes Hayman surveyed women visual artists about their experience of art at colleges and universities in 1980, almost $73 \%$ mentioned discouragement from male professors. The survey found that, during their training, $92 \%$ of the women respondents had fewer than $10 \%$ women teachers. ${ }^{105}$ Yet, women students have in the past dominated and continue to dominate undergraduate fine arts programmes. In 1988 , they represented $65 \%$ of the students graduating with a Bachelor's or first professional degree in fine and applied art and $59 \%$ of those gaining Master's degrees in Canada. ${ }^{106}$ In 1995 (the most recent year for which Statistics Canada has published figures), 2,776 women and 1,418 men graduated as majors in the fine and applied arts from Canadian universities. ${ }^{107}$ In the same year, 306 women and 181 men received Master's degrees in the fine and applied arts. Since the MFA remains the terminal degree requirement for most visual arts studio teaching positions at Canadian universities, this is a particularly significant statistic. ${ }^{108}$ (Statistics Canada also reports that in 1995, 16 women and 24 men received doctorates in the fine and applied arts. ${ }^{109}$ )

Statistics Canada's "Profile of Higher Education in Canada" reports that, at the college level in Canada in 1986-87, fulltime male teachers outnumbered women by the ratio of two to one. In universities, men outnumbered women faculty by almost five to one. ${ }^{10}$ The employment profiles of university faculty were succinctly summarized: "Most full-time university teachers are males over 40 years of age who hold the rank of associate or full professor ... In all age categories, the proportion of males at the rank of full professor is higher than the proportion of females at that rank. Conversely, in all age categories, the proportion of females below associate professor is higher than that of males at that level." 111 Little had changed ten years later. In 1995-96, at the university level, women made up only about $24 \%$ of university faculty. ${ }^{112}$

In comparison with these general employment statistics for women teaching at the post-secondary level, those for women employed in studio teaching in the visual arts have been even more problematic. Women faculty in university studio teaching positions have historically been part-time, poorly paid, nontenure-stream faculty - positions which were the first to go in times of economic pressure. (In the disciplines of film, theatre and music, until relatively recently, it was not uncommon to find major Canadian university departments with no full-time female faculty.)

Concordia University is one of the few post-secondary institutions that has historically hired women full-time in the studio area. In the fall of 1999 , fifteen of its full-time faculty are women ( 2 full professors and 3 tenure track) and thirteen are men ( 2 full professors and 5 tenure track) in the Department of Studio Arts. The majority of studio classes taught by full-time and contractually limited appointments are taught by women.

The situation has improved generally in the last several years as a cadre of faculty hired in the late 1960s and the 1970s have begun to retire and women are being appointed to the tenure-track positions which have become available. York University offers a fairly representative example of Canadian studio programmes. In the fall of 1999, seven of the thirteen full-time studio faculty members in the Visual Arts Department are tenured men (two of whom are full professors). Six faculty members are women (none of them are full professors, and three are in tenure-track positions); most of these are relatively recent appointments. At the same time, approximately twothirds of the Department's studio courses in 1999-2000, taught by full-time, contractually limited and part-time appointments, will have male instructors. ${ }^{113}$

A 1995-96 study of American studio departments under- 
taken by the College Art Association reflects a similar situation. ${ }^{114}$ Women represented $36 \%$ of the tenured faculty, though only $24 \%$ of those were at the level of full professor; $41 \%$ of studio teaching was done by women. (The fact that the response rate was just over $50 \%$, with only 120 of 230 surveyed institutions responding, suggests that a full response rate would likely reflect significantly poorer statistics. ${ }^{115}$ )

While many post-secondary institutions adopted affirmative action programmes in the 1980s, the Ontario College of Art and Design's "Equity 2000" (in a discrete and uni-purpose institution dedicated to the visual arts) offers an excellent opportunity to follow the results of such a programme. OCAD launched the first phase of its employment and educational equity plan in 1989. The programme's purpose was to increase significantly the percentage of women teaching art and design at the College. An affirmative action programme, reserving positions vacated by retiring faculty for qualified women faculty, was deemed essential because several years of "best effort" hiring had resulted in no increase in the percentage of women teaching. ${ }^{16}$ Prior to the implementation of the plan, women represented approximately $20 \%$ of the teaching faculty. On the announcement of the plan, a campaign was launched, primarily by male faculty members at the College, threatening that implementation of the plan would result in a reduction in the quality of teaching and dire consequences for the College if it were to proceed. The College, under the leadership of Tim Porteous, refused to be intimidated.

A 1993 summary of the progress of the plan indicated that since 1989-90, the percentage of teaching by women faculty had increased from $21.7 \%$ to $35.5 \%$ in the academic year 1993-94. At the same time, the number of senior women administrators also increased significantly. ${ }^{177}$ In 1997-98, the percentage of teaching by women faculty had increased to $37.2 \%$. After the implementation of the plan, each year except one showed an increase in the percentage of teaching done by women. Anomalously, 1996-97 showed a reduction to $34 \%$, suggesting that continued progress cannot be taken for granted. ${ }^{118}$ In 1998-99, 39\% of teaching was done by women, surpassing the current Equity target of 38\% for the year 2000. ${ }^{119}$ (Though the 1993 projection for $1999 / 2000$ was to have $46.3 \%$ of teaching done by women, the target appears to have been adjusted to reflect more accurately the rate of progress. ${ }^{120}$ ) With its clearly defined goals and objectives, OCAD has been among the most successful post-secondary institutions in Canada in improving the percentage of studio teaching by women.

\section{Conclusion}

Much has been accomplished in the last two decades. Following the 1970s wave of feminism and the intensive challenges to accepted hierarchies, Canadian women artists gained greater recognition both at home and abroad. Artists such as Betty Goodwin and Liz Magor have been selected by Canadian curators to represent Canada internationally. The work of these and a number of other artists, such as Jana Sterbak, has been featured in exhibitions organized by galleries and museums around the world. ${ }^{121}$

The practice of women artists has been instrumental in shaping the post-modernist aesthetic discourse in Canada, pioneering discussions around representation and the construction of gender and race and consciously seeking to construct a new aesthetic. Jamelie Hassan, Leila Sujir, Joanne Cardinal-Schubert and Jane Ash Poitras are just a few of those exploring these questions, examining parricularly the hierarchies of representation and the politics of gender and representation. Canadian women artists have achieved international recognition for their work in installation, video and multi-disciplinary work. Women art historians, curators (many of them free-lance), critics and administrators dealing with issues of gender and race have been key catalysts for change in creating the critical climate in which women's work is viewed. Significantly, women artists have been at the forefront of the parallel gallery movement, establishing new venues in which their work can be seen. Women editors of publications like C Magazine and Parachute have enhanced the climate for critical discussion.

The case studies discussed in the first part of this paper, though limited in their scope, offer evidence of the significantly improved situation for women artists in Canada. Women are being written back into history and their work incorporated into public collections. Yet, the evidence also suggests that their inclusion has been largely within existing hierarchical structures. (In the case of Wieland, in particular, critics largely formulated a position for her as the binary opposite to the maleness of the still dominant canon.) Though these artists have disrupted the canon, their positioning within the discourse of Otherness has often served to reinforce the canon itself and the female artist's marginalization.

Indeed, that women artists in Canada have accomplished so much in the face of what remain significant odds is remarkable. The ideologies and market conditions which confer a diminished value on women's work have not disappeared. Despite conscious efforts on a number of fronts, the work of women artists is less likely to be commissioned, performed or exhibited than that of their male colleagues in a system still strongly influenced by a gendered hierarchy of value. Women are still less likely to hold university teaching positions or to receive as much grant money as their male counterparts. They will, in most cases, earn less as well. In this chicken-and-egg situation, women artists are less likely to have a national or international reputation or find themselves included in the 
canon, still pre-conditions for success in the contemporary visual arts world.

Even as I write this paper, I realize its limitations. Many scholars would argue that my approach does not address the root causes of inequality. I would agree. Indeed, like the task of first-generation feminist scholars recuperating women artists lost to history (as was the case with Kathleen Munn), this work is essentially retrospective in nature. The theorization of patriarchy, identity and gender are essential to changing the nature of the art world and to the creation of the new historiography. The materialist approach that I have adopted here is intended to provide a benchmark, reflecting real vs. imagined progress and defining specific institutional challenges for the future. Continued assessment is critical, as is the establishment of consistent criteria for the evaluation of progress.

The facts make it evident that the recuperation of women artists as Other into the dominant discourse will not suffice. Within the Canadian arts community, we still require a consolidation of feminist scholarship and innovative strategies to rework traditional approaches to the theory and history of art. We need not only to correct the history books but to expand the historical framework and insist upon a new historiography which, as Griselda Pollock foresees, will expand and alter the discourse to be fully inclusive.

\section{Notes}

1 Griselda Pollock, "Women, Art and Ideology: Questions for Feminist Art Historians," Visibly Female: Feminism and Art: an Anthology, ed. Hilary Robinson (London, 1987), 203.

2 An earlier version of this paper looking at Canadian women artists in the visual arts, theatre and music was published in Monica Verea and Graciela Hierro, eds, Las mujeres en America del Norte al fin del milenio (Mexico, 1998), 343-68. I am indebred to Carol Podedworny for her critical reading of this text and her suggestions, to Claire McCaughey at the Canada Council for the Arts and to Janice Seline and Johanna Mizgala at the National Gallery of Canada for their assistance. I have borrowed the title, $A$ Tale of Three Women, from Griselda Pollock, Differencing the Canon: Feminist Desire and the Writing of Art's Histories (London, 1999).

3 Monika Gagnon, "Work in Progress: Canadian Women in the Visual Arts," in Rhea Tregebov, ed., Work in Progress: Building Feminist Culture 1975-1987 (Toronto, 1987). See Linda Abrahams, "Who Counts and Who's Counting," Matriart, VI, no. 1 (1996), 6-9; and Penelope Stewart (for the Women's Art Resource Centre), "Survey on the Status of Canadian Women in the Arts 1994: Statistics on the National Gallery of Canada for the Years 1970 and 1993," Matriart, VI, no. 1 (1996), 10-14. See also Maria Tippett, By a Lady: Celebrating Three Centuries of Art by Canadian Women (Toronto, 1992).

4 Pollock, Differencing the Canon, 24. Pollock argues that this is the case because art history's "mythological and psychic centre is fun- damentally exclusively not to do with art and its histories but with the Western masculine subject, its mythic supports and psychic needs."

5 Report of the Federal Cultural Policy Review Committee, Ottawa, Information Services, Department of Communications, Government of Canada, January 1982, 20. In their brief, the Vancouver Status of Women organization reported that "the creative works of women have been implicitly and explicitly neglected."

6 Pollock, Differencing the Canon.

7 See Pollock, Differencing the Canon, 12.

8 Newton MacTavish, The Fine Arts in Canada (Toronto, 1925), 144. MacTavish described the work of fourteen highly talented women and listed twenty-two others of acknowledged ability. Many had won international awards for their work.

9 Albert H. Robson, Canadian Landscape Painters (Toronto, 1932), 176.

10 Fred Housser, "The Amateur Movement in Canadian Painting," Yearbook of the Arts in Canada, ed. Bertram Brooker (Toronto, 1929), 89.

11 This discussion, as is the case with much of the discussion about Kathleen Munn, is based upon my work in Joyce Zemans, Elizabeth Burrell and Elizabeth Hunter, Kathleen Munn and Edna Tacon: New Perspectives on Modernism in Canada, exh. cat., Art Gallery of York University (Toronto, 1988).

12 MacTavish, The Fine Arts in Canada; Housser, "The Amateur Movement;" and Robson, Canadian Landscape Painters.

13 Dennis Reid, A Concise History of Canadian Painting (Toronto, 1973). Munn is mentioned in Graham McInnes, $A$ Short History of Canadian Art (Toronto, 1939), 86, where, unusually, in noting her achievements in graphic art, McInnes discussed her in the context of her peers, Bertram Brooker and Walter Phillips. In Paul Duval's Canadian Drawings and Prints (Toronto, 1952), unpaginated, she was described as "one of [Canada's] most original religious artists," rather than being singled out as a woman artist. In Russell Harper's Painting in Canada: A History (Toronto, 1966), 358-59, though there is an illustration of a work, then in Brooker's collection, documentation is limited and suggests that he may not have known her work first hand. He wrote that "she became a leading woman painter in Canada and retained an interest in Cubism as an effective art style."

On a more general level, an analysis of general books on the arts in Canada written in the decade between 1975 and 1985 is revealing. The percentage of women who were involved as writers or discussed as artists ranged from a low of $7 \%$ in W.J. Keith and B.Z. Shek, eds, The Arts in Canada: The Last Fifty Years (Toronto, 1980 ), to a high of $14 \%$, where the artists were discussed in some depth, in Robert Fulford, An Introduction to the Arts in Canada (Toronto, 1977). Other books included were George Woodcock's Strange Bedfellows: The State and the Arts in Canada (Vancouver, 1985), and Dean Walker, ed., The Arts in Canada: Today and Tomorrow (Toronto, 1976). Anne Innis Dagg, The 50\% Solution (Waterloo, 1986), Table 2-1, "Contribution of Women in Books on the General State of the Arts in Canada."

14 Though Charlotte Schreiber (1834-1922) was a charter member 
of the RCA's 40-member permanent body in 1880 , her status was similarly limited.

15 Tippett, By a Lady, 39, cites Newton MacTavish, "Laura Muntz and Her Art," Canadian Magazine, XXXVII, no. 5 (Sept. 1911), 419.

16 It was likely through Brooker that Munn was incroduced to the Tovells, who were among the few who collected her work.

17 Tippett, By a Lady, 39, points out that, like Toronto's Arts and Letters Club, other major art societies in Canada, Montreal's Pen and Pencil Club and the Canadian Art Club, remained exclusively male.

18 Frederic!: Housser, A Canadian Art Movement (Toronto, 1926), 72.

19 Tippett, By a Lady, 55.

20 Housser, "The Amateur Movement," 89. Male teachers also dominated the Ecole des Beaux-Arts and the Art Association School in Montreal, as well as the Victoria School of Art and Design in Halifax, although the majority of their students were female.

21 Hill does not have a record of receipt of this letter. Munn's anxiety was evident in the various copies of the letter found amongst her possessions after her death which suggest that the letter was rewritten many times.

22 Kathleen Munn and Edna Tacon: New Perspectives on Modernism in Canada, Art Gallery of York University, Oct. 13-Nov. 13, 1988. In 1989, the exhibition travelled to the Art Gallery of Windsor (Windsor), Concordia Art Gallery (Montreal), The Edmonton Art Gallery (Edmonton), the McIntosh Gallery (London), and the Agnes Etherington Art Centre (Kingston). In 1990 it was exhibited at the Robert McLaughlin Gallery (Oshawa).

23 Reid, A Concise History of Canadian Painting, 328.

24 Kay Armatage, "Kay Armatage Interviews Joyce Wieland," Take One, III, no. 2 (Nov.-Dec. 1970), 24.

25 In 1967, Wieland had spoken of her belief in "Man art" and "Woman art." Barrie Hale, "Joyce Wieland: Artist, Canadian, Soft, Tough, Woman!" The Telegram, 11 March 1967. Mayo Graham, Some Canadian Women Artists, exh. cat., National Gallery of Canada (Ottawa, 1975), has noted the unusual variety of materials used by Canadian women artists, including textile art forms and the prevalence of serial or cumulative themes.

26. See Lauren Rabinovitz, "Issues of Feminist Aesthetics: Judy Chicago and Joyce Wieland," Woman's Art Journal, I, no. 2 (Fall/ Winter 1981), 38-41.

27 Rabinovitz, "Issues of Feminist Aesthetics," 41.

28 Linda Hutcheon, Splitting Images: Contemporary Canadian Ironies (Don Mills, 1991), 104.

29 Susan Crean, "Forbidden Fruit: The Erotic Nationalism of Joyce Wieland," This Magazine, XXI, no. 4 (1987), 12.

30 John Bentley Mays, "AGO Retrospective Enshrines the Myths Surrounding Joyce Wieland," The Globe and Mail, 18 April 1987, C15.

31 Mays, "AGO Retrospective." In this section on the critical response to Wieland's work I am drawing on the unpublished manuscript by Jill Raschka titled, "Joyce Wieland's Self-Portraits," completed as a requirement for the M.A. Programme in Art History at York University in 1995.
32 Harry Malcolmson, "Joyce Wieland," The Telegram, 25 March 1967.

33 Hale, "Joyce Wieland," 21.

34 Adele Freedman, "Roughing it With a Brush," The Globe and Mail Magazine, April 1987, 41.

35 P. Adams Sitney, "Structural Film," Film Culture, no. 47 (Summer 1969), 1-10.

36 See Lauren Rabinovitz, "The Films of Joyce Wieland," Joyce Wieland, exh. cat., Art Gallery of Ontario (Toronto, 1987), 120.

37 Kay Armatage, "Joyce Wieland's Water Sark," Canadian Woman's Studies, VIII, no. 2 (Spring 1987), 84. Cf. Sirney's limited description of the film as "devolv[ing] through images created by moving a camera around and through glasses filled with different colours of water." P. Adams Sitney, "there is only one Joyce," artscanada, XXVII (April 1970), 43.

38 Kass Banning, "The Mummification of Mommy: Joyce Wieland as the AGO's First Living Other," in Sightlines, Jessica Bradley and Lesley Johnstone, eds (Montreal, 1994), 153-67.

39 As the Dean of the Faculty of Fine Arts at York University at the time (1985), I was shocked to find how much lower, comparatively speaking, women's salaries were than men's, despite similar accomplishments. The situation could be traced back, in part, to the fact that many women, in the negotiations around hiring, did not feel comfortable bargaining to obtain a higher starting salary. (The result was that, since salary increments were almost always based on a percentage of existing salary, the gap continued to widen.)

40 See Vera Frenkel, "Almost Broken: A Stroll at the Edge of the Cliff," a talk given at the Universities Arts Association of Canada Annual Conference, Guelph, October 1995, subsequently published in RACAR, XXI (1994 [published 1996]), 1-6.

41 Vera Frenkel, interview with the author, 26 February 1999.

42 With Lost Art: A Cargo Cult Romance (1986), she began a cycle of work examining the attribution of meaning, false messiahs and millennial fantasies, investigations which continued with This is Your Messiab Speaking (1990-91), a two-channel video installation and computer animation disseminated via London's Piccadilly Circus Spectacolor Board. Her stand against censorship is the focus of The Business of Frightened Desires: Or the Making of a Pornographer (1985).

43 Lydia Haustein, "The Transformative Power of Memory: Themes and Methods in the Work of Vera Frenkel," Vera Frenkel: ... from the Transit Bar, exh. cat., The Power Plant (Toronto, 1994), 61.

44 Vera Frenkel, interview with the author, 26 February 1999.

45 Haustein, "The Transformative Power of Memory," 79.

46 Haustein, "The Transformative Power of Memory," 73.

47 Vera Frenkel, interview with the author, 26 February 1999.

48 Museum of Modern Art, Department of Film and Video Press Release, September 1998: VideoViewpoints: Vera Frenkel.

49 Frenkel's 1985 work, The Business of Frightened Desire: Or the Making of a Pornographer, a slide/sound installation, is in the Art Bank collection.

50 Vera Frenkel, interview with the author, 26 February 1999.

51 Statistics Canada, Cultural Labour Force Survey, 1993, 14, Table 
5b: "Median Income of People Working in Selected Primary Occupations, 1993," 13, Table 5a: "Average Income of People Working in Selected Primary Occupations, 1993." Amongst visual artists in 1993 , the median income from their cultural work was $\$ 4000$, while their overall income was $\$ 10,000$. The average income, which is more often quoted, was $\$ 7800$ from cultural work and $\$ 14,100$ total income. (The median is a better measure than the average since it eliminates any bias caused by including a small number of highly paid artists.) The average income of women artists was approximately half that of their male counterparts. Women represented 4000 vs. 3000 men who declared their primary occupation as painters, sculptors and related artists. 4800 women described themselves as musicians or engaged in other music occupations vs. 8500 men. In the case of actors and other performers, 2400 were women and 4800 men. In the case of writers, 4100 women described themselves this way vs. 4300 men, but 4300 women identified with the category of "other writing occupations" vs. 3100 men. See Cultural Labour Force Survey, 11, Table 4a: "Gender, by Primary Occupations, 1993." The percentage of women artists in the cultural labour force in 1993 was $46.9 \%$.

52 Abrahams, "Who Counts and Who's Counting," 6, reported, after surveying gender representation at the National Gallery of Canada, that "the results ... statistically expos[e] inequities which [are] shocking and contrary to public perceptions of the current status of Canadian women in the arts."

53 Dagg, The 50\% Solution, 16. The report also noted that, although most administrators in the arts were men, it was women who had founded each of the major ballet companies in Canada and a woman who led the National Gallery of Canada.

54 Dagg, The 50\% Solution, 20.

55 National Gallery of Canada annual reports indicate that between 1990 and 1995, four works by Munn were purchased by the Gallery.

56 Garry Mainprize, "The National Gallery of Canada: A Hundred Years of Exhibitions, List and Index," RACAR, XI (1984), 1-2. Featured artists included Les Levine, Joe Plaskett, Gershon Iskowitz and Walter Redinger (XXXVI International Biennial Exhibition of Art Venice, 1972), Claude Tousignant, Moshe Safdie, Greg Curnoe, Albert Dumouchel, Norman White, Greg Curnoe (XXXVII Venice Biennial, 1976), Guido Molinari, Jack Bush, Paterson Ewen, Ivan Eyre, Ron Martin and Henry Saxe (XXXVIII Venice Biennial, 1978), Michael Snow (Paris, Musée National d'Art Moderne, Centre Georges Pompidou, 1978), Charles Gagnon, John Hall, Greg Curnoe (Retrospective). Note: All of these exhibitions were documented with a pamphlet or catalogue; those in italics were accompanied by a major catalogue of at least 68 pages and in most cases berween 100 and 200 pages; I have included neither exhibitions, such as the 1974 cxhibition Photographs by Charles Gagnon, for which no documentation was listed nor solo exhibitions of work drawn from the collection, of which there were several.

57 Mainprize, "The National Gallery of Canada."

58 Mainprize, The National Gallery of Canada." Historic solo or major two-person exhibitions of the work of male artists in the decade following Wieland's July 1971 exhibition included Adrien Hebert, Thomas Davies, Paul Kane, Bertram Brooker, Alfred Pellan, Robert Harris, Ozias Leduc, Edwin Holgate, Frederick Arthur Verner, John Vanderpant, James Wilson Morrice, Lionel LeMoine FitzGerald, Walter Phillips, Joseph Legare, George Heriot, William Brymner and Daniel Fowler. Exhibitions in italics were documented by major catalogues.

59 Virtually all of the major Wieland works in the collection were acquired in the 1970s, many of them at the time of the exhibition in 1970 or 1971 and many of the films in 1974 . Only a few works were acquired after 1979. (Experiment with Life, 1983, was purchased in 1983; Paint Phantom, oil on canvas, 1984, was purchased in 1985; and a drawing, The Birth of Perception, 1981, was acquired in 1991.) In more recent years, the in-depth collecting of a single artist's work has been replaced by an attempt to build a broader collection. Fax from Janice Seline to Joyce Zemans, 13 November 1996.

60 Frenkel was disappointed in the documentation for this exhibition; translation problems held up the publication of the brochure which was only made available at the end of the exhibition; interview with the author, 26 February 1999. It was only ca. 1990 that a budget for documentation of video exhibitions was established; phone conversation with former NGC curator, Sue Ditta, 9 June 1999. (Rebel Girls, a survey of Canadian feminist videotapes from 1974 to 1988 , curated by Ditta in 1989, was documented by a one-sheet folded programme.)

61 From Frenkel's perspective, the use of Bill C18 (passed in 1991) was a mixed blessing. Although it allows a $100 \%$ tax credit against earned income for donated works of "outstanding significance and national importance" and permits the artist to use the credit in any given year within a six-year window, the artist must have sufficient income to make it worthwhile.

62 Clive Robertson, "Re-Mandating the Local? Museum Acquisitions and the Contextualization of Canadian Contemporary Art," Parachute, 76 (Oct., Nov., Dec. 1994), 68-71.

63 Robertson, "Re-Mandating the Local?" 70.

64 Dagg, The 50\% Solution, 16.

65 Dagg, The 50\% Solution, 53-54, Table 4-3: "Display of Largely or Entirely Canadian Art at Canadian Public Galleries." Percentage of Canadian works by women: NGC, 4\%; Art Gallery of Ontario, $9 \%$ of those exhibited in the Canadian galleries (it had also installed the exhibition Toronto Painting of which $28 \%$ were by women); the Vancouver Art Gallery, 20\%; The Winnipeg Art Gallery, 18\%; Edmonton Art Gallery, 9.5\%; Hamilton Art Gallery, 17\%; Kitchener-Waterloo Art Gallery, 10\%; Art Gallery of Nova Scotia, 20\%; Macdonald Stewart Art Centre, 5\%. Only the Art Gallery of Greater Victoria had fewer works by Canadian women on display: its Canadian selections from the 1950s and 1960 s included 15 artists but no women.

66 David Burnett and Marilyn Schiff Burnett, Contemporary Canadian Art (Edmonton, 1983).

67 David Burnett, Masterpieces of Canadian Art from the National Gallery of Canada (Edmonton, 1990). (I have considered General Idea as one artist.) 
68 Major historical exhibitions by women were Paraskeva Clark: Paintings and Drawings curated by Mary E. MacLachlan for the Dalhousie Art Gallery, 1983; Cecil Buller: Modernist Printmaker curated for the Glenbow Museum by Patricia Ainslie, 1989; and Emily Carr, curated by Doris Shadbolt and Charles Hill, 1990.

69 Solo exhibitions by male artists from July 1981 to the end of 1991 included the following: in 1981, Greg Curnoe: retrospective; in 1982, Fred Varley, Paterson Ewen (for the 1982 Venice Biennale); in 1983, David Heath, A.Y. Jackson, Cultural Engineering: Tom Sherman, Maurice Cullen; in 1984, Murray Favro, Ian Carr Harris (and Liz Magor for the 1984 Venice Biennale), E. J. Hughes, Denis Juneau, John O'Brien: Marine Painter; in 1986, Melvin Charney and Krzystof Wodiczko (for the 1986 Venice Biennale). The National Gallery closed between September 1987 and May 1988 in preparation for the move to the new building. In 1988, Ivan Eyre; in 1989, Paterson Ewen: Phenomena Paintings; in 1990, Eric Cameron: The Divine Comedy, Ron Martin, James Wilson Morrice, Pudlo and Colin Campbell. (Note: exhibitions in italics are considered major. I have considered several two-person exhibitions organized for the Venice Biennale in this account since each artist has been given full consideration. My criteria for a "major exhibition" include a substantial catalogue. While some of these exhibitions originated in other galleries, the fact that the National Gallery exhibited them indicates the conferral of a high degree of recognition.)

In the period 1992-97, major solo exhibitions included Sara Diamond: memories revisited, history retold (1992) and, in 1993, Correspondences: Jack Shadbolt, and Don Wright; in 1995, Roland Poulin, Paul Wong: On Becoming a Man, and Vera Frenkel's ... from the Transit Bar; in 1996, Betty Goodwin: Signs of Lifelsignes de vie; in 1998, Emanuel Hahn and Elizabeth Wyn Wood: Tradition and Innovation in Canadian Sculpture.

70 Cited in Abrahams, "Who Counts and Who's Counting?" 6.

71 Penelope Stewart (for the Women's Art Resource Centre), "Survcy on the Status of Canadian Women in the Arts 1994: Statistics on the National Gallery of Canada for the Years 1970 and 1993," Matriart, VI, no. 1 (1996), 10-14. In 1970, 150 living women artists (13.8\%) and 937 living male artists were represented in the Canadian collection. In 1993, there were 880 living women (25\%) and 2641 living male artists. There were 155 Canadian women artists (18.1\%) represented in the Permanent Collection in 1970 , represented by 472 works (10.3\%), compared to 701 male artists, represented by 4096 works. In 1993 there were 416 women (18.1\%) represented by 1548 works (12.4\%) and 1881 male artists $(10,978$ works)

72 Stewart, "Survey on the Status of Canadian Women." In 1970, there were 10 women artists $(6.4 \%)$ represented by 16 works (4.3\%) and 146 male artists represented by 359 works. In 1993, there were 18 women artists (8.5\%) represented by 38 works $(6.2 \%)$ and 195 male artists represented by 574 works.

73 National Gallery press release, "National Gallery of Canada, Works by Contemporary Canadian Women Artists in the Contemporary Galleries," November 1993. The exhibition of works from the permanent collection commemorated the twentieth anniversary of the Canadian Advisory Council on the Status of Women. Nancy
Spero was the only non-Canadian in the exhibition; her work was a recent acquisition.

74 The central room of the lower galleries was dedicated to a solo presentation of the work of Yves Gaucher in this installation. In the spring of 1996, the lower galleries included 18 works by Joyce Wieland and an installation of Nancy Graves' work. Janice Seline, Assistant Curator, Contemporary Art, The National Gallery of Canada, telephone interview, 10 Oct. 1996.

75 E-mail, 24 February 1999, from Johanna Mizgala to Joyce Zemans, re. Exhibition statistics.

76 Sasha McInnes-Hayman, "Permanent Collection Acquisitions February 1981-March 1982," (1982) cited in Dagg, The 50\% Solution, 61: $\$ 11,770$ (2.15\% of the budget for Canadian art) was spent on the work of Canadian women artists, \$534,344 on the work of Canadian men. (The tocal acquisitions budget was $\$ 2,379,614$.)

77 Stewart, "Survey on the Status of Canadian Women in the Arts 1994." In 1970, the National Gallery spent $\$ 4,513$ (0.75\%) for the work of women artists in general and $\$ 602,945$ for the work of men. In 1993, the National Gallery spent $\$ 432,758$ (11.27\%) on the work of women artists and $\$ 3,407,060$ on works by men.

78 "Acquisitions/Purchases of Post-1945 Works by Women and Men, National Gallery of Canada Fiscal Year 1997-98," Johanna Mizgala, Curatorial Assistant, Contemporary Art, National Gallery of Canada, E-mail, 6 January 1999; and "Average Prices Paid for Post-1945 Works by Women and Men, NGC," E-mail, 11 January 1999.

79 "Average Prices Paid for Post-1945 Works by Men and Women Narional Gallery of Canada." This table, prepared by Janice Seline, Assistant Curator of Contemporary Art, November 1996, examines Gallery acquisitions between 1990-91 and 1995-96. In the $\$ 5000$ to $\$ 9999$ range, 14 works by women and 38 by men were purchased $(26.9 \%)$. In the $\$ 10,000$ to $\$ 49,999$ range, 20 works by women and 74 by men were purchased (21.3\%). See also Mizgala, "Acquisitions/Purchases," and "Average Prices."

80 Mizgala, "Acquisitions/Purchases," and "Average Prices."

81 National Gallery of Canada, Annual Report 1995-96, 81. Agnes Martin (American, b. 1912), White Flower I, 1985. Acrylic and graphic on canvas, $183 \times 183 \mathrm{~cm}$.

82 Robertson, "Re-mandating the Local?" 68.

83 Mizgala, "Acquisitions/Purchases."

84 Mizgala, "Acquisitions/Purchases."

85 See, for example, Robert Fulford, "The Artifice of Prices in the Art Market Economy," The Globe and Mail, 14 August 1996, C1. Fulford describes the art market and its artificial (as he deems it) prices, attributing the high costs of art works to what he calls "Envy Pricing" and "Government Pricing." See also the reply by Ydessa Hendeles, "Magicians of the Art World Cast a Spell," The Globe and Mail, 31 August 1996, D1.

86 See Annette Van den Bosch, "Women Artists' Careers and Public Policy and the Market," in Ghosts in the Machine: Women and Cultural Policy in Canada and Australia, Alison Beale and Annette Van den Bosch, eds (Toronto, 1998), 211-22

87 "Occupation: Artist: A Profile of the Demographic Economic and 
Employment Characteristics of Artists in Ontario," Toronto, Ontario Arts Council, 1992, 56. In 1978 women represented 60\% of the worst paid of the arts community - what the Canada Council called the "sub-proletariat." Laurent Mailhot and Benoit Melancon, Le Conseil des Arts du Canada 1957-1982 (Montreal, 1982), 48, 92.

88 See Martha Woodmansee, The Author, Art, and the Market: Rereading the History of Aesthetics (New York, 1994). This is the case although a number of major dealers have been women. Lucy R. Lippard, From the Centre: Feminist Essays on Women's Art (New York, 1976), 31, has accounted for the number of women dealers and their lack of promotion of women artists by arguing that the roots of this discrimination can probably be traced to the fact that making art is considered a primary function, like running a business or a government, and women are conventionally relegated to secondary, housekeeping activities such as writing about, exhibiting, caring for the art made by men.

89 Stewart, "Survey on the Status of Canadian Women in the Arts 1994."

90 Federal Cultural Policy Review Committee: Summary of Briefs and Hearings (Ottawa, 1982), 93. Without question, the largest public collector of contemporary Canadian art has been the Canada Council Art Bank. Its programme of acquiring contemporary Canadian art for rental for installation in government facilities and in other public places (1972-95) was instrumental not only in establishing the careers of individual artists but also in the development of the network of Canadian private galleries which, in the early days, represented the principal source of acquisitions for the Art Bank. After a number of complaints in the late 1970 s and the Martin study of Council selection procedures, the Art Bank also increased the participation of women on its juries. The result was an increased number of acquisitions of works by women - placing the acquisition of women's work at about one-third that of men. However, the Bank continued to purchase far more works by men than women. Moreover, it spent over twice as much money on each male as on each female artist. The ratio in terms of acquisitions has continued to improve although records for the last year of Art Bank acquisitions (1994-95) indicate that less than half of the works acquired in that year were by women. See the Canada Council Annual Report 1994-95, 99-101. In this year a total of 306 works were acquired at a total cost of $\$ 660,495$. Based on a rough estimate, not including artists whose names were not gender specific, of 195 artists whose work was collected, 80 were women.

91 Jane Martin, "Who Judges Whom: A Study of Some Male/Female Percentages in the Art World," Atlantis, V (1979), 127-29. See also Jane Martin (survey undertaken for the Canadian Artists Representation / Le Front des Arristes Canadiens, CARFAC), "Women Visual Artists on Canada Council Juries, Selection Committees and Arts Advisory Panels; and amongst Grant Recipients from 1972-73 to 1979-80." In 1975-76, out of thirty-one jurors, only one was a woman, and she was not an artist. The proportion of money given to women was almost always less than the proportion of women requesting money. There were two exceptions in the field of dance.
92 Martin, "Who Judges Whom?"

93 The Canada Council for the Arts, Table 1c: "Number of Canada Council Jurors, Assessors and Advisors according to Gender and Language by Disciplines (1) 1994-95." Fax from Claire McCaughey, Staristics and Research Officer, Arts Service Unit, 30 Seprember 1996. What is most shocking in these figures is that, while most disciplines average around $45-50 \%$ female jurors, music remains at $26.7 \%$. (In dance, which has always been heavily female, $61.2 \%$ of the jurors are female.)

94 The Canada Council for the Arts, Table 2b: "Canada Council Juror, Assessor and Advisor Services. Gender and Language by Discipline (1) 1994-95." Fax from Claire McCaughey, 30 September 1996.

95 The Canada Council for the Arrs, Table 2b: "Juror, Assessor and Advisor Services."

96 Statistics Canada, Cultural Labour Force Survey, 1993, Table 4b: "Gender, by Primary Occupations," 1993. Women represent 70\% of the professional crafts field and 55\% of Canada's designers. In the case of the categories "directors, producers and choreographers" and "musicians and other music occupations," 64\% are men and $36 \%$ women. $77 \%$ of all dancers are women while $66 \%$ of actors and other performers are male. In the case of writers, $51 \%$ are male.

97 Statistics Canada, Cultural Labour Force Survey, 1993, Table 5b: "Median Income of People Working in Selected Primary Occupations, 1993" and Table 5a: "Average Income of People working in Selected Primary Occupations, 1993."

98 The Canada Council, "Trends in Support to Artists by Discipline, Gender and Program," 1981-82 to 1991-92. Fax from Claire McCaughey, 19 August 1996.

99 David Foote, Boom, Bust and Echo (Toronto, 1996). Women entered professional practice in large numbers at the end of the 1970s, an inauspicious time, demographically, given the comperition.

100 The Quest awards are valued up to $\$ 7000$. A short-term programme, it will run for only 1999-2000 and 2000-01; there will be only two competitions.

101 The Canada Council For the Arts: "Applications, Success Rates and Grants Awarded to Professional Visual Artists, by Visual Arts Sub-Discipline and Gender, 1997-98." Fax from Claire McCaughey, 3 August 1999.

102 The Canada Council, "Applications, Success Rates and Grants Awarded to Professional Visual Artists, by Visual Arts Sub-Disciplines and Gender, 1997-98."

103 The Canada Council, "Applications, Success Rates and Grants Awarded to Professional Visual Artists, by Visual Arts Sub-Disciplines and Gender, 1997-98." Similar statistics are apparent in the case of architecture: 36 men applied vs. 15 women; the success rate for men was $30.56 \%$ vs. $20.00 \%$ for women, and the total funds allocated were $\$ 114,000$ for men and $\$ 64,000$ for women. In the case of crafts, the applications numbers were similar: 108 men and 103 women; the success rate was also similar, $23.15 \%$ for men and $22.33 \%$ for women. In the case of total grants, men received $\$ 398,000$ (average of $\$ 15,920$ per 
grant), and women received $\$ 331,000$ (average of $\$ 14,391$ per grant).

104 Dagg, The 50\% Solution, 6.

105 Dagg, The 50\% Solution, 59, cites Sasha McInnes Hayman, "Contemporary Canadian Women Artists: A Survey," Report for the Status of Women of Canada, 1980.

106 Statistics Canada, Education in Canada, 1997 (Ottawa, 1997), 17-18, Tables 3.10, 3.11 and 3.12. Women constituted $64 \%$ of the students graduating with a Bachelor's or first professional degree in fine and applied art in 1978 and 65\% in 1988, and $53 \%(1978)$ and 59\% (1988) of those gaining Master's degrees (the terminal degree for teaching in the studio in the visual arts field); in the humanities (which include fine arts doctoral studies), $30 \%$ of doctoral degrees were awarded to women in 1978 and $40 \%$ in 1988.

107 Statistics Canada, Education in Canada, 1997, 139, Table 37: "Bachelor's and first professional degrees granted, by field of study and sex, Canada, 1991 to 1995." In 1995-96, 930 women and 646 men were enrolled in graduate programmes in the fine and applied arts in Canadian universities; see Statistics Canada, Education in Canada, 1997, 75, Table 16: "Full-time enrolment, by field of study and sex, Canada, 1991-92 to 1995-96." In 1995-96, there were 11,152 women and 6,611 men enrolled as full-time students in the fine and applied arts in Canadian universities; see Statistics Canada, Education in Canada, 1997, 63, Table 14: "Full-time undergraduate enrolment, by field of study and sex, Canada, 1991-2 to 1995-96." In 1996, 54\% of the Ontario College of Art and Design's and 65\% of York University's graduating class were women.

108 Statistics Canada, Education in Canada, 1997, 151. Table 39: "Master's degrees by field of study and sex, Canada, 1991 to 1995."

109 Statistics Canada, Education in Canada, 1997, 155. Table 41: "Earned doctorates, by field of study and sex, Canada, 1991 to 1995."

110 Statistics Canada, "Profile of Higher Education in Canada," Education Research and Promotion Directorate, Education Support Branch, Department of the Secretary of State of Canada (Ottawa, December 1990), 10/11. Table 2.3 illustrates the number of fulltime post-secondary teachers, by level and sex, Canada, 1986-87: there were 14.3 thousand full-time male college teachers and 7.6 thousand women. There were 29.2 thousand full-time male university teachers and 6.2 thousand women.

111 Statistics Canada, "Profile of Higher Education in Canada," 12, Tables 2.7 and 2.8 .

112 Statistics Canada, Education in Canada, 1997, 168.

113 York University, Department of Visual Arts, "Visual Arts Timetable - 1999/2000 (17/08/99)." Two of the tenured women faculty are on sabbatical or leave for the 1999/2000 academic year. (I have not included in these calculations retired faculty who continue to teach one course per year. In the studio area, two of these are men, and one is a woman. In the case of tenured faculty in art history, four are women, four are men (a fifth holds a tenurestream appointment), and there is one retired male faculty mem- ber who continues to teach one course in an academic year.

114 Committee on Women in the Arts, "Survey on the Status of Women and People of Color in the Arts: 1995-96." The Committee on Women in the Arts of the College Art Association collected data between April 1996 and April 1998; it was chaired by Kathleen MacQueen and Marjorie Och. Figures available from the College Art Association website: www.collegeart.org/caal aboutcaalwomen. They are based on responses from $120 \mathrm{MFA}$ granting institutions out of the 230 surveyed. In 1987-88, 80 of the $230 \mathrm{MFA}$ granting institutions responded. At that time women represented $33 \%$ of the total faculty, $27 \%$ of the full-time faculty and $18 \%$ of full professors. In 1995-96, women of colour represented $3 \%$ of all faculty members; $2.5 \%$ were full-time faculty, and $0.5 \%$ were full professors. In the $1987-88$ survey, $1.5 \%$ of all faculty were women of colour; they represented only $1 \%$ of fulltime faculty and were not reflected in the statiscics for full professors.

115 Committee on Women in the Arts, "Survey on the Status of Women." The American figures offer better results when MA/ $\mathrm{PhD}$ degree granting programmes are considered. In the 140 institutions which responded, $31 \%$ of the total faculty were women, and women represented $48.50 \%$ of full-time faculty, though they only represented $37 \%$ of the cohort of full professors. (In 1978-79, women received 66\% of the PhDs in $43 \mathrm{PhD}$ granting art departments in accredited institutions. Mary Garrard, Women's Caucus of the College Art Association, survey of the status of women in 43 of $45 \mathrm{PhD}$ granting art departments in accredited institutions of higher education, April 1981.)

116 Equity 2000: Phase I, 1990. See Ontario College of Art, Equity 2000 Newsletter, "The Process Begins," January 1990. Equity 2000: Phase II also focused on Native people, disabled people and visible minorities. See Equity 2000 Newsletter, "The Process Continues," October 1990; see also Equity 2000 Newsletter, no. 1, 7 October 1991; Newsletter, no. 2, 28 October 1991; and Newsletter, no. 3, 11 November 1991. See also the 1991 report, "Equity 2000: Phase II: Employment and Educational Equity: Ontario College of Art: Recommendations from Equity Phase II Committee to OCA Council," 11 November 1991, typescript.

117 Background material (typescript), "Report of the OCA task force on the Progress of Phase I of Equity 2000," Toronto, 1990.

118 "Review of Equity 2000 Phase 1 Progress, Faculty Periods 198997." The ordinary measurement of numbers of full-time tenured faculty members is not appropriate in this case. Rather, the figures are tabulated in terms of the numbers of periods taught by women since the Ontario College of Art and Design (OCAD) has, since the 1970s, hired faculty on a permanent part-time and full-time basis. Figures provided by Connie Areses-Resi, Administrator, Human Resources, OCAD, 22 February 1999. Note: 1996-97 has been called the "bumping year" in which downsizing resulted in more recent faculty appointments being "bumped" to accommodate need to reduce expenditures.

119 Review of Equity 2000: Phase 1 Progress: Faculty Periods - 1989 to 1998,4 August 1999. Fax from Jessica Wyman, Office of the VP Academic, OCAD, to Joyce Zemans. 
120 Fax from Nicky Davis, Human Resources Administrator and Employment Equity Coordinator, 16 November 1993, to Joyce Zemans. Davis includes "Employment Equity Statistics" (filename: EEPROGR). This document predicted, "There will be a total of 72 periods vacated by male faculty through retirement by the year 2000. With the assumption that these are all filled by qualified women, the percentage of classes taught by women will reach $46.3 \%$ by the year 2000." (Predicting that, since non-designated hiring would be "more gender-balanced than in the past," the document also noted that financial restraints which frceze retirement periods might result in "less progress from earmarked periods.")
121. The work of Jana Sterbak has been collected in some depth by the National Gallery of Canada. There are five major sculpture/ installation works by the artist, as well as a painting, a print and a drawing in the collection. This work has been widely circulated to major international exhibitions of contemporary art at venues such as London's Tate Gallery and Chicago's Museum of Contemporary Art. In Sterbak's casc, while four sculpture/installations have been purchased by the gallery, one was gifted, as were the smaller works, by the artist or her former dealer, Ydessa Hendeles. 